\title{
IMPACT OF FISCAL POLICY SHOCKS ON OFFICIAL VERSUS PARALLEL EXCHANGE RATE OF SUDAN: UNDER LONG-TERM ECONOMIC SANCTION AND SOUTH SUDAN REVERONDUM (1997-2017)
}

\author{
Ibrahim A. Mohammed Belal ${ }^{*}$ \\ Sumaya Awad Khader Ahmed ${ }^{2}$ \\ ${ }^{* 1}$ Associate Professor, Department of economic, Peace University-Sudan \\ ${ }^{2}$ Assistant Professor, Department of Economics, Academy of Science-Sudan, \\ Department of Business Administration, Al-Jouf University-Saudi Arabia
}

This journal is licensed under a Creative Commons Attribution-NonCommercial 4.0 International License (CC-BY-NC).

Articles can be read and shared for noncommercial purposes under the following conditions:

- BY: Attribution must be given to the original source (Attribution)

- NC: Works may not be used for commercial purposes (Noncommercial)

This license lets others remix, tweak, and build upon your work non-commercially, and although their new works must also acknowledge you and be non-commercial, they don't have to license their derivative works on the same terms. License Deed Link: http://creativecommons.org/licenses/by-nc/4.0/

Legal Code Link: http://creativecommons.org/licenses/by-nc/4.0/legalcode

$A B C$ Research Alert uses the CC BY-NC to protect the author's work from misuse.

\begin{abstract}
We analyze the impact of fiscal policy shocks on official and parallel exchange rates in Sudan under two extreme circumstances over the period1997-2017, using standard structural VAR framework, supported by Impulse Response Function IRFs to investigate the performance and transitory shocks on exchange rate systems, at first the stationary of the variables is obtained to avoid the specious of the model. The result of long run analysis shows that lag fiscal policy expressed by LGt; lag official exchange rate (Loexrt) and lag economic openness( Leopent) have significant positive impact on parallel exchange rate, on the other hand lag Gross Domestic Product(LGDPt) and LGt variables shows significant impact on official exchange rate, with respect to IRFs, the shock of fiscal policy on Loext only significant in the short run; while in the long run it deserve no effect, hence South Sudan referendum shows negative impact on LGt, which mean that Sudanese government fiscal policies did not achieved the targeted objectives, concerning US economic sanction results indicates that it is one of the main factors of parallel exchange rate volatility and encouragement of black market of foreign currencies. The study recommend the important of a comprehensive packages of fiscal and monetary policies; unification of multi-exchange rate system; rationalize taxes and duties to combat smuggling and the need to increase exports and encouraging inflow of remittances of Sudanese working abroad.
\end{abstract}

Keywords

Fiscal policy shocks, official versus parallel exchange rate, IRFs.

\section{INTRODUCTION}

Real exchange rate is a very important variable in macroeconomics, which plays a vital role to determine the degree of competitiveness among the economies. After the failure of Bretton Woods system in a year 1973, Stable and competitive real exchange rate is very important for developing countries as well as for underdeveloped ones, as it has a significant impact on 
the foreign direct investment flows, international trade, growth rate of GDP, inflation, balance of payment and capital mobility. Many scholar have investigated the relationship between exchange rate and various macroeconomic variables, they emphasized the existence of strong relationships and significant causality between these variables. Not ignoring the importance of monetary policy in determining exchange rate fluctuation, one can observe fiscal policy shocks as determinant of exchange rate volatility has been given less attention in recent macroeconomic literature. Analysis of expansionary or discretionary fiscal policy shocks in dynamic general equilibrium model depends on whether the shock was permanent or temporary. many studies assessed fiscal policy shocks under economic sanction, Perotti (2002), proposed new and interesting methodology to identify fiscal policy shocks in VARs, with quarterly data by exploiting decision lags in policy making, and information about elasticity's of fiscal variables to economic activity. Notwithstanding, other studies such as Mountford and Uhlig (2009) assess the effects of fiscal shocks under a different methodology, that consists in imposing some sign restrictions to impulse response functions. Goldberg and Klein (1997) examine the relationship between foreign direct investment and real exchange rate in some underdeveloped and developing countries, the result shows that there are significant relationship between bilateral real exchange rate and FDI. Caballero and Corbo (1998) investigate that in which conditions the degree of uncertainty and risk about the real exchange rate adversely affect the export earning, and their performance, further they found very strong and significant negative relationship between them in case of underdeveloped countries. Thus, verifying the means of exchange rate fluctuation is significant if exchange rate is to be obtained; it is useful to be able to measure and differentiate between, relative significance of perpetual and transitory shocks on real exchange rate. This paper investigate the responsiveness of exchange rate to the long- term shock of fiscal policies during USA economic sanction which implemented on Sudan since 1997. The sanction had has many adverse impact on socio-economic and cultural settings of Sudan, our emphasis is on economic side to work out how Sudanese government react with respect to changes of macroeconomic policies to maintain the economic progress which achieved before the sanction . U.S.A sanction to Sudan not only lead to lack of foreign currencies but also encourage existence of parallel market of exchange rates (black market) and the gab between the two markets was widen reaching almost about 66\% in September 2017 compared to about $20 \%$ in 2013 (IMF, country report no.320,2013), it also encourage a multiple exchange rates system, in this respect Sudan's exchange rate regime pivots around the following rates (1) central rate of SDG 4.42 per US dollar, that applied also to importation of fuel products(2) subsidized for wheat of SDG 2.9 per US dollar(3) Gold exchange rate used by central bank in its Gold transaction (4) commercial bank rate to all other transactions. Notwithstanding, Sudan exchange rates witnessed continuous devaluations and interventions due to , first loss of most of oil resources as a result of the secession of South Sudan; secondly due to US economic sanction which became effectively in 1997.therefor understanding critically exchange rate volatility under these extreme circumstances becoming of great challenge, for both the researcher and economic policy makers to put forward a proper economic plans in order to stabilizes exchange rate fluctuations. In this paper we use the "exactly identified" structural vector auto regression (VAR) approach, which has been used in many empirical studies to analyses the dynamic impact of Sudanese government fiscal policy on real exchange rate during the period of economic sanction; more specifically Impulse Response Function well be employed to test for fiscal shocks, Richard. C \& Joe.p(1999) employed the same approach. The contribution of this paper is, to fill the gap in literature on the impact of fiscal policy on exchange rate fluctuations and diversifications 
under long- run economic sanction in Sudan; as most empirical studies focused on identifying the determinants of equilibrium exchange rate and impact of monetary policy (Ebiadalla,2013).

\section{OVERVIEW OF EXCHANGE RATE POLICY IN SUDAN:}

Exchange rate policies in Sudan, showed different system since the independence of Sudan in 1956.It applied fixed exchange rate, intermediate exchange rate arrangements and currently managements (Khalid.A,2011). The fixed exchange rate applied during the period between 1956-1971, with two systems they are;(1) currency board management until 1960 (2) the credible fixed exchange rate approach from 1960-1971, then incredible fixed exchange followed from 1972-1996 with different sub-systems extended from the period of fixed-like to rabid frequencies reduction in exchange rate; while managed floating exchange rate applied from 1997 till now (Alkhalifa etal, 2009) .

Since 1997, Sudan has been working with IMF, which advice for implementing of macroeconomic reform including managed floating exchange rate (IMF, report 2010), as said by IMF exchange rate flexibility is a key to rebuild foreign exchange reserves accounts for exchange rate fluctuations can reduce pressure on general price level and maintain favorable balance of payment, particularly after fall in international oil price, low oil revenues associated with South Sudan referendum and the implementation of U.S.A economic sanction to Sudan. During the late 1970,s and beginning of 1980,s , Sudanese government employed first version of the stabilization and liberalization programs, among others the program focused on exchange rate devaluation; as a result Sudanese pound has been depreciated to the rate of one US dollar equal 0.35 Sudanese pound aiming at encourage exports; attracting foreign direct investment (FDI) and reducing external imbalances, it is the first time for monetary authority to announce the dual exchange markets namely, official and parallel exchange markets (Mahjoub,2013). Through 1980,s exchange rate is again witnessed continuous devaluation, when the country suffer from sever lack of foreign reserve, as a result of 1985,s famines and arises of civil war in 1983; thus the official exchange rate set at LS 2.5/US dollar and the parallel market at LS3.3/US dollar, in 1987 exchange rate devaluated further to about LS4.00/US dollar and LS5.8/US dollar for the two markets respectively, in the late 1989 black market exchange rate is rabidly increased reach about more than LS20/US dollar. The new regime of "Elngaz" government in early 1990s imposed various structural economic changes, were the economy witnessed several transformations from government control through 1970-1989 to free market policies; accordingly the exchange rate received considerable attention from the government, since it considered as a key factor effecting economic instability, as a result the black market exchange rate was prohibited and all foreign exchange transactions were confirmed to the commercial banks; in spite of that exchange rate reported as higher than in 1980s . but in the late 1990s commercial oil was exploited 1n 1999 and become major sources of foreign currency, as a results exchange rate shows substantial stability with limit rate at 2.650-2.600/US dollar, during the period 2008-2010 the exchange rate shows many fluctuations with increasing rate, owing to the reduction in export quantities and international oil price slump , there for resulted in split of exchange markets in to official and black market of exchange and later on in to multi-exchange rate systems. Over all, the exchange rate in Sudan witnessed continuous devaluation since 1970s for the whole period before and after oil exploitation. The following figure display the development of exchange rate during different exchange rate systems. 


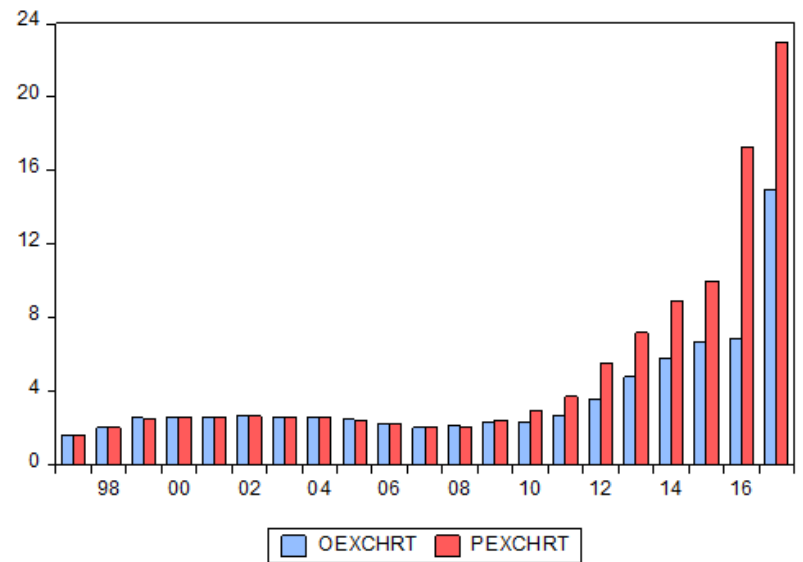

Figure(2-1) official versus parallel exchange rate in Sudan(1997-2017) Source: researcher own calculation result of Eviews9 soft ware.

From the above figure, official and parallel exchange rate were almost shows stable and constant ratio during the period 1997-2010, but after 2011 the gap between the two rates started to widen, it reach about 54\% in 2012,then it reach it is peak in 2017 about $66 \%$ with an expectation of further deterioration of Sudanese bound.

\section{LITERATURE REVIEW:}

Exchange rate is the price of a domestic currency in terms of other currencies. It is usually determined by the interaction of supply and demand for money in a free market setting. The main objectives of exchange rate policy are to conserve the value of the domestic currency, sustain a favorable external reserves position and ensure external balance without compromising the need for internal balance and macroeconomic stability as a precursor to economic growth. The earliest theoretical foundation for the choice of exchange rate regimes rested on the Optimal Currency Area (Gilbert Deinde Ifarajimi, 2017). According to the theory, a fixed exchange rate regime can increase trade and output growth by reducing exchange rate uncertainty and thus the cost of hedging, and also encourage investment by lowering currency premium from interest rates. However, it can also reduce trade and output by stopping, delaying or slowing the necessary relative price adjustment process.. The OCA theory claimed that a fixed regime can also delay the necessary relative price adjustments and often lead to speculative attacks. Therefore, many developing and emerging economies suffer from a "fear of floating" (Calvo and Reinhart, 2002), as managed floating regimes also often end in crashes when there is a "sudden stop" of foreign investment and capital flight follows, which suit the situation in Sudan in 1997 after the shock of economic sanction and after 2011 when South Sudan decided referendum. When a currency depreciates, the exchange rate movement has two potential implications for economic growth. First, it reduces that country's wages and production costs relative to those of its foreign counterparts.. Secondly, the understanding of the stock price-exchange rate relationship may prove helpful to foresee potential crisis, and trying to avoid the risk arising from exchange rate uncertainty through involvement in unofficial transactions. Notwithstanding the issue of parallel exchange rate versus official exchange rate has raised a considerable policy attentions in both the developed and underdeveloped countries. because the gab between the two would lead to great impacts on macroeconomic performance, that is, pressures on inflation, lower GDP growth, unattractiveness of investment and low export performance. In theory, parallel markets for foreign exchange rate explained and analyzed via three approaches;(1) Real trade 
models to explain the emergence of parallel exchange to the exchange rate restrictions and heavy government interventions in trade, which have negative implications of making excess demand for foreign currency which in turns create black market for foreign currency (Nowak,1984), this theory shows that, the supply of foreign currency in the parallel exchange market comes from five sources they are; smuggling of exports; under-voicing of export; under-voicing of imports; foreign tourists; remittances of nationals working abroad and diversion of foreign currency from official to the parallel market through corruption.(ii) portfolio-balance approach: this approach was developed by De macedo (1987),which emphasized the role of foreign currency as an asset in portfolio composition, because loss in confidence in domestic currency lead to changing composition between foreign and domestic currency, which in turns determine the size of parallel market for exchange rate. (iii) Monetary approach :emphasized the role of money supply, since an increase in money supply lead to inflation and increase demand for foreign currency in parallel market, on other hand it can creates excess demand for goods and services and as such resulted in inflationary pressures, which inevitably lead to future depreciation of exchange rate causes parallel market rate to further appreciate(Ebiedalla,2017)

\section{PREVIOUS STUDIES}

Empirically, several studies have been conducted to investigate the determinants of parallel exchange rate. For example, Degefa (2001) investigated the determinants of parallel foreign exchange market and its effect on macroeconomic performance in Ethiopia. His results show that real money balances, real effective exchange rate and inflow of aid have positive effect on parallel market premium in the long-run. On the while, the terms of trade negatively affects the premium only in the short run. He also found that inflation is Granger-cause the parallel exchange rate premium. Aron and Elbadawi (1992) investigated the determinants of parallel premium for exchange rate in Zambia using a portfolio model of parallel market exchange rate. Adopting annual data over the period 1970-1987, they found that the interest parity differential and the change in the stock of real domestic money are the most significant factors affecting positively the parallel exchange rate premium. Their results also show that the term of trade and foreign aid grants have negative and significant effect on exchange rate premium.

In the same vein, Elbadawi (1992) studied the determinants of parallel exchange rate in Sudan, using a portfolio approach. He attributed the emergence of black market premium to miss-invoicing and smuggling of exports and imports, and diversion of remittances of expatriates to the black market for foreign exchange. He also found that real exchange depreciation has a significant negative effect on the premium in the both short and long run. Finally, the author pointed out that trade liberalization policy exerts negative and significant impact on the parallel market premium .Moreover, Nkurunziza (2002) examined the factors that affecting parallel exchange rate premium in Burundi using annual time series data for the period 1970-1988. Adopting co- integration and error correction model, his results show that expected rate of devaluation, economic growth and trade policy are the most significant factors influencing parallel exchange rate premium. Siddiki (2000) investigated the determinants of parallel market premium in India over the period 1965-1994. His results reveal that the parallel market for foreign exchange is influenced significantly by the official exchange rate, trade liberalization, foreign reserves, and by the interest rate. In addition, he found that the application of flexible Breton Woods exchange policies of 1973 have negative 
and significant impact on parallel market. Moreover, his results show that real per capita income, money supply and political instability do not have any significant effect on parallel exchange rate premium. On the other hand, The two common empirical methodologies used to estimate of the effects of fiscal shocks are panel methods and vector autoregressive models (VARs). Using panel methods, e.g., Galstyan and Lane, 2009, and Ricci et al., 2013 find that real exchange rates appreciate in response to fiscal stimulus shocks. Apparently, VARs are more likely to find the opposite. Numerous empirical studies have investigated the effect of fiscal policy shock on exchange rate volatility and diversifications, although studies are not all in agreement, in addition did not take attention to the impact of parallel exchange rate, this paper will bridge this gab. The depreciation of the exchange rate of the Sudanese pound has been a major reason for various problems which the Sudan economy has been experiencing and this has made it extremely difficult to predict the direction of the Sudanese economy with any degree of accuracy. The potentially higher cost of imported input associated with pound depreciation increases marginal cost and leads to higher prices of domestically produced goods (Kandil, 2004). In the same vein, local firms increase prices in response to foreign competitors' price increase to improve profit margins (leading to escalating inflation) especially in the absence of product substitutability. In the process of achieving macroeconomic stability, Sudan's monetary authorities have adopted various exchange rate arrangements over the years. It shifted from a fixed regime in the 1970s to a pegged arrangement between the 1970s through the mid-1980s and finally to the various types of the floating regimes since 1986 (Dada \& Oyeranti, 2012; Eze \& Okpala, 2014) but none of the various policies have been able to stabilize the Pound. The purpose of this study is to examine the impact of fiscal policy which implemented during shocks period to elevate exchange rate fluctuations and diversifications (multi-exchange rate system) and performance on economic growth in Sudan. The study covers the period 1997 (when U.S imposed economic sanction) to the year 2017. The main questions being addressed are the effects of government expenditure as a proxy of fiscal policy ; economic openness as proxy for foreign policy and GDP growth on exchange rate under these extreme conditions .

\section{ECONOMETRICS MODEL}

To achieve research objectives, the analysis follows two steps, first we identifies the determinants of parallel market exchange rate in the short run and long run , secondly we identify the determinants of official exchange rate (the same equation can be employed putting official exchange rate as dependant variable) then testing the effects of fiscal policy shocks on the two rates . despite of several models which employed to analyze the effects of fiscal policy shocks, our study depended on portfolio-balance model developed by Kiguel and O,connel(1994), but with some modifications on macroeconomics variables of concerns. Thus the estimated equation of parallel exchange rate could be expressed as follows:

PEXRt $=\beta_{\mathrm{o}}+\beta_{1} \mathrm{OEXPt}+\beta_{2} \mathrm{GDPt}+\beta_{3}$ EOPENt $+\beta_{4} \mathrm{Gt}+\beta_{5}$ PEXRt- $1+\beta_{6}$ DUM97 + $\beta_{7}$ DUM11 + Ut

Were, PEXRt is parallel exchange rate were Sudanese bound is exchanged with foreign currencies out side the banking sector; OEXRt refer to official exchange rate set by central bank of Sudan; GDPt is gross domestic product ;EOPENt is economic openness expressed by dividing total export over GDP ; G refer to government expenditure; PEXRt-1 is lag parallel exchange rate, DUM97-DUM11 are two dummy variables, the first DUM97 capture the USA economic sanction which take the value of one during the period (1997-2017) while the other capture the period after South Sudan referendum, which takes the value 1 during 
2011-2017 and zero before referendum1997-2010, $\beta_{\mathrm{o}} \ldots \beta_{\mathrm{n}}$ are the coefficients to be estimated and $U$ is the error term. All the variables will expressed in logarithm form. The second step is to investigate the impact of government expenditure as a proxy for fiscal shock on parallel exchange rate and on official exchange rate respectively. Following previous studies on parallel and official exchange rate determinants e.g... the first model can be expressed as follows:

$\mathrm{OEXR}_{\mathrm{t}}=\beta \mathrm{X}_{\mathrm{t}}+\alpha \mathrm{G}_{\mathrm{t}}+\mathrm{U}_{\mathrm{t}}$

Were; $\mathrm{X}$ is the vector of control variables which include, economic openness (EOPEN),consumer price index (CPI) and foreign direct investment(FDI). According to economic theory $\mathrm{G}$ is expected to have positive impact on official exchange rate, since an increases in $\mathrm{G}$ would lead to more deteriorations on Sudanese pound, which may raise official exchange rate ; CPI is assumed to have positive impact, a rabid increases in general price level associated with deterioration in official exchange rate and hence encourage imported inflation.GDP growth expected to have negative impact on official exchange rate if it is accumulated from increases in real out put more specifically export goods varieties. Economic openness which is the reflection of international transactions is expected to have positive impact on official exchange rate, because it increases inflow of foreign currency. With respect to FDI it expected to have positive impact on official exchange rate since it increase inflow of foreign capital inform of foreign currency. Secondly with respect to the impact if government expenditure $(G)$ on parallel exchange rate we follow Aron and Elbadawi(1992) model , but with some modifications of their model , there for the estimated equation of parallel exchange rate versus $\mathrm{G}$ is specifies as follows:

$\operatorname{PEXR}_{\mathrm{t}}=\beta \mathrm{X}_{\mathrm{t}}+\alpha \mathrm{G}_{\mathrm{t}}+\mathrm{U}_{\mathrm{t}}$

Where, PEXRt is parallel exchange rate ; $X_{t}$ is vector of control variables ; $G_{t}$ is government expenditure and $U$ is error term, we use also two dummy variables to reflect the fiscal shock. According to economic the impact of $\mathrm{G}$ on parallel exchange rate is positive, since an increase in $G_{t}$ lead to an increase in imported goods and services which in turn generate great pressures on demand for foreign currency, thus parallel exchange increases. with respect to CPI it assumed to have positive impact on PEXR $_{t}$, while $\mathrm{GDP}_{t}$ will negatively affect PEXR because increases in output lead to increases in exports, which stimulate the supply of foreign currency and hence discourage black market of exchange rate, but FDIt and EOPEN expected to be positively impact on PEXR . To analyze the impact of fiscal policy on official versus parallel exchange rate in Sudan, we employ simple Vector Aut-Regressive model (VAR) supported by Impulse Reponses Function (IRF). Use of VAR model helps account for spurious correlations and require no endogenous- exogenous division of variables, in addition this techniques distinguish clearly between long and short run impacts and providing tool for policy analysis (Ahmed Badwi (2002) . in equation (1) is one of 6 equations where all variables are defined in term of other variables(their lag variable) and variables own lagged value(all variables in natural logarithm). VAR model with two lag in each variable (including constant) would be employed in line with Maddala(1992) as follows:

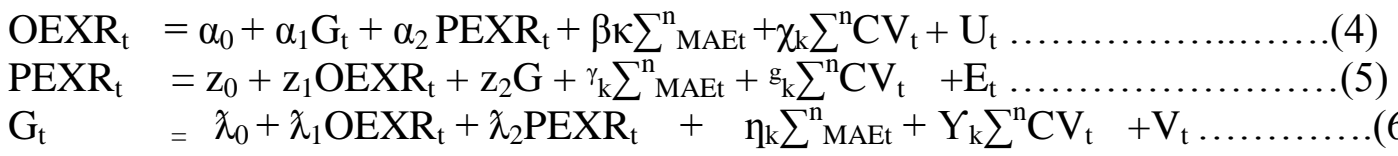


$\alpha, \beta, \chi, z, \gamma, g, \chi$ and $\eta$ are coefficients to be estimated according to equations $(4,5,6)$ while $U_{t}, E_{t}$ and $V_{t}$ error terms in their respective equations.

The essence of specifying VAR equations is to obtain the Impulse response functions and forecast error variance decomposition to explain the various shocks effects of variables to one another. The IRF tell us how target variables respond to shocks in the policy variables and control variables; while the variance decompositions shows the magnitude of the variations in the target variables due to the policy variables and control variables(Gilbert\&Daniel,2017).

\section{EMPIRICAL RESULTS:}

This section discusses the results and empirical analysis of the impact of fiscal policy shocks on official and parallel exchange rate in Sudan. Firstly, we test for the properties of time series using Unit Root test by employing Augmented Dickey-Fuller(ADF) and Philips-Perron(PP) tests; secondly, checking the determinants of official and parallel exchange rate ,thirdly; estimating unrestricted VAR and ; fourthly, we run Impulse Response Function.

\subsection{Testing for Stationary}

Before employing empirical analysis techniques it is useful to test for the existence of stationary in the series under study. The results of the unit root test for each variables are reported in table (6-1)

\begin{tabular}{|l|l|l|l|l|l|l|}
\hline test & \multicolumn{3}{|c|}{ ADF } & \multicolumn{3}{|c|}{ PP } \\
\hline variables & t-stat. & Prob. & level & t-stat. & Prob. & level \\
\hline FDI $_{\mathrm{t}}$ & 4.2 & 0.0052 & $1_{\mathrm{st}}$ difference & 3.1 & 0.04 & level \\
\hline Eopen & 5.3 & 0.0004 & $1_{\mathrm{st}}$ difference & 5.3 & 0.0004 & $1_{\mathrm{st}}$ difference \\
\hline $\mathrm{CPI}_{\mathrm{t}}$ & 3.8 & 0.0117 & $1_{\mathrm{st}}$ difference & 4.4 & 0.0027 & $1_{\mathrm{st}}$ difference \\
\hline $\mathrm{GDP}_{\mathrm{t}}$ & 4.1 & 0.0057 & $1_{\mathrm{st}}$ difference & 3.6 & 0.0155 & $1_{\mathrm{st}}$ difference \\
\hline $\mathrm{G}_{\mathrm{t}}$ & 7.5 & 0.0000 & $2_{\text {and }}$ difference & 2.9 & 0.0539 & $1_{\text {st }}$ difference \\
\hline Oexr $_{\mathrm{t}}$ & 2.9 & 0.0511 & $2_{\text {and }}$ difference & 11.1 & 1.0000 & insignificant \\
\hline Pexr $_{\mathrm{t}}$ & 4.4 & 1.0000 & insignificant & 5.8 & 0.0002 & $2_{\text {and }}$ difference \\
\hline \multicolumn{7}{|c|}{ Table (6-1) Unit Root tests } \\
\hline
\end{tabular}

Referring to results in table (6-1), the coefficients of the all variables entered in the model are stationary significant at least $5 \%$ level accept $\mathrm{FDI}_{\mathrm{t}}$ shows insignificant effects; this mean that the null hypothesis of no co-integration between the variables is rejected, in other word there exist long run relationship between parallel exchange rate and economic openness, government expenditure, gross domestic product, consumer price index and official exchange rate. In addition there is variation in the level of the stationary of the variables with respect to the two test displayed.

\subsection{Determinants of parallel exchange rate.}

To identify the factors that effecting parallel exchange rate in Sudan, equation (1) is estimated and the results summarized in the following table.

\begin{tabular}{|l|l|l|l|}
\hline variables & Co-efficient & t-stat. & Prob. \\
\hline Lfdi $_{\mathrm{t}} *$ & -0.102 & -0.770 & 0.453 \\
\hline Leopen $_{\mathrm{t}} *$ & -1.638 & -3.679 & 0.002 \\
\hline LG $_{\mathrm{t} * * *}$ & 0.787 & 0.188 & 0.000 \\
\hline LGDP $_{\mathrm{t}} * *$ & 1.370 & 0.540 & 0.022 \\
\hline Loexr $_{\mathrm{t} * *}$ & 0.980 & 0.150 & 0.000 \\
\hline Adjusted $\mathrm{R}^{2}$ & $90 \%$ & & \\
\hline DW & 2.5 & & \\
\hline
\end{tabular}
Table(6-2) Determinants of parallel exchange rate in Sudan during the period (1997-2017)
Source: researcher estimation using Eviews9
Note: ***, **,* indicate significance at 1,5 and 10 percent respectively


The results of long run analysis shows only LGt and Loexr $r_{t}$ variables have significant positive impact on parallel exchange rate and satisfy the expected sign of economic theory, this mean an increase in government expenditure or official exchange rate will increase parallel exchange rate. While the coefficient of $\mathrm{FDI}_{t}$ is positive but insignificant, interestingly the coefficient of Leopen $\mathrm{t}_{\mathrm{t}}$ is positively affect $\operatorname{Lpexr}_{t}$; which implies that foreign trade policy did not have any contribution to reduce parallel exchange rate in long run; with respect to LGD Pt growth shows negative impact on parallel exchange, thus it is not consistent with economic theory, it shows typically that long run declining in total production has significant impact on parallel exchange rate . The effect of Leopen ${ }_{t}$ found to have positive and significant on parallel exchange rate; this result imply that the central bank of Sudan exchange rate policies has contributed to raise the rate of parallel exchange rate in Sudan. the coefficient of determination $\left(\mathrm{R}^{2}=90 \%\right)$ is very high, which mean that the variables entered in the model would explain about $90 \%$ of variation in parallel exchange rate market; the model also did not suffer from the problem of autocorrelation since $\mathrm{DW}=2.5$.

\subsection{Determinants of official exchange rate}

To identify the factors that effecting official exchange rate in Sudan, equation (1) is estimated and the results summarized in the following table.

$\mid$\begin{tabular}{|l|l|l|l|}
\hline variables & Co-efficient & t-stat. & Prob. \\
\hline $\mathrm{LG}_{\mathrm{t} * * *}$ & 6.600 & 4.704 & 0.000 \\
\hline $\mathrm{LGDP}_{\mathrm{t} * *}$ & -0.269 & -3.281 & 0.004 \\
\hline Dum97 & -12.480 & -3.004 & 0.007 \\
\hline Adjusted $\mathrm{R}^{2}$ & $92 \%$ & & \\
\hline DW & 1.9 & & \\
\hline
\end{tabular}
Source: researcher estimation using Eviews9
Note: ***,**,* indicate significance at 1,5 and 10 percent respectively

Referring to above table, only LGDPt; LGt and Dum97 regarded as main determinants of official exchange rate, because they showed high significant; other variables such as LFDIt, eopent and LCPIt are insignificant therefore omitted from the analysis, the sign of most of the variables did not follow the assumptions of economic theory; this mean that parallel exchange rate is regarded as illegal activities did not given any serious attention by economic policy makers. On the other hand, central bank of Sudan monetary policies in general and more specifically exchange rate policies witnessed continuous changes and shows high instability and contiguous devaluation of Sudanese Pound during the last five years, which in turn has negative consequences on parallel exchange rate. In addition Central Bank of Sudan exchange rate policies fail to attract inflow of foreign exchange and to utilize all quantity of Gold which produced as a result of smuggling. With respect to Dum97, which stand for U.S economic sanction shows significant negative impact on official exchange rate; this indicates US economic sanction is responsible for continuous devaluations; exchange rate fluctuation and instability in foreign exchange market in Sudan.

\subsection{Vector Auto-Regression (VAR) Estimates:}

To examine the response of variables to shocks within the system and the variations within the system . The variables included are; Loexrt, LGt, and LGDPt as policy variables, table(5-4) shows VAR order selection criteria; Akaike information criteria indicates lag 2 is the most efficient; there for unrestricted VAR is estimated on lag 2, the VAR results indicate that none of the explanatory variables exert any strong influence on official exchange rate, 
which mean shocks rather than effect translate in to economy. Therefore emphasis will be given to analysis of Impales Reponses Function.

\subsection{Response of Official Exchange to Fiscal Policy Shock under South Sudan referendum:}

To explain the variation and fluctuation of each variables to another (other shock) and to itself (own shock) . According to figure (5-1) the response of Loexrt to shock of fiscal policy is negative in short run; while in the long run the result shows no effect. Hence results shows one shock on official exchange rate would have positive effect on government expenditure in short run; while in the long run deserve no effect. Concerning South Sudan referendum represented by dumo11 it is clearly shows positive impact on official exchange rate, which mean official exchange rate fluctuation during the period of the study is explained by this dummy variable. But South Sudan referendum as an external shock shows negative effect on government expenditure at least in the short run. The explanation of these results is that, it can be observed from the above figure, that the response of official exchange rate even when there is reduction of government expenditure is ineffective therefore exchange rate will increase significantly due to continuous devaluation of Sudanese Pound during this period, this result indicate that government fiscal policy did not achieve the targeted objectives.

\subsection{The Response of Official Exchange Rate to fiscal policy shock under U.S economic sanction:}

Referring to figure (5-2) the response of official exchange rate to fiscal shock is negatives both in short run and long run, the result of IRF also shows negative effect of official exchange rate on government expenditure. This means that official exchange rate regarded as one of the main variables which influence government expenditure in short and long run in Sudan during the period of U.S economic sanction. With respect to Dum97 results shows that it has positive effect on official exchange rate, which mean that U.S economic sanction is one of the main factor of exchange rate deterioration in Sudan. Our empirical results is different from the many pervious work in several ways; for example, Rogers(1999) and Clarida\&Prendergas(1999), did not estimate simultaneously the effects of fiscal policy shocks on official exchange rate and parallel exchange market, in contrast this study compare the effects of fiscal policy shocks on the two variables including two dummy variables to capture for external shocks, also results in this study shows that the effect of fiscal policy shocks in is different with respect to official and parallel exchange market, although the mentioned studies found the relationship is a symmetric .

\subsection{The Response of Parallel Exchange Rate to fiscal policy shock under U.S economic sanction:}

U.S economic sanction to Sudan which became effective in 1997, induced number of economic obstacle which have adverse implications, among others results presented in figure(5-3) indicate that, Parallel exchange rate responded positively to U.S economic sanction; which regarded as one of the main factors responsible for parallel exchange fluctuations, while parallel exchange rate response negatively to government expenditure in the long run; with respect to parallel exchange rate it has only short run negative effect on government expenditure, but in the long run it has no effect. 
The Response of Parallel Exchange Rate to Fiscal policy shock under South Sudan referendum:

Figure (5-4) display analysis results of the Impulse Response Function of parallel exchange rate to one standard deviation in government policy over horizon of 1 to 10 years. Results indicate that the effect of shock of government expenditure (Gt) support our previous findings, the response of pexrt to the shock of fiscal policy under South Sudan referendum is negative both in short and long run, the same result is applicable for the response of Gt to pexrt, results shows that pexrt response negatively to shock of South Sudan referendum.

\section{CONCLUSION AND RECOMMENDATIONS:}

Review literature of exchange rate policies in Sudan reflected great ambiguity about it is overcome and effects on several economic indicators, referring to the results and discussions we present the main concluding points as follow:

1- Analysis results based on two scenarios, indicates that shock of South Sudan referendum is the most effective factors were scarcity of foreign exchange reserve has been occurred, due to loss of about seventy percent of oil revenues after a separation in 2011; which imposed a significant negative impacts on official and parallel exchange rates; therefore monetary policy makers embarked on continuous devaluations of Sudanese pound against the main foreign currencies, which resulted in multi-exchange rates system.

2- Government of U.S imposed long run package of economic sanctions in 1997, which mainly designed to restrict many financial transactions, resulted in several negative shocks, more specific on official and parallel exchange rates market.

3- The pressures in exchange rate market put many constraints on fiscal and monetary policies which lead to high exchange rate fluctuations; decreases of foreign reserve and rabid increases in parallel exchange rate market.

4- One can observe that fiscal policy and unstable financial policies push up parallel exchange rate to work as a lead for exchange market, which resulted in continuous up word movement.

5- Study results shows that, fiscal policy shocks in Sudan is effective only in the short run as a tool to stabilize exchange rate deterioration during the wave of continuous budget deficit and trade deficit (the twin deficit)

6- With respect to the main sources of foreign currencies, the central bank of Sudan financial policies failed to attract the remittances of considerable numbers of Sudanese working abroad; on the other hand it did not succeed to manage Gold exports as a result two third of total production of Gold lost through smuggle, other exports declined because of declining in the main production sectors mainly(cash crops, Sugar and Oil )

7- Concerning custom duties, recent policies induced great devaluation of Sudanese pound against US dollar from about 7.6 to about 18 pounds and within not more than a weak one US dollar set equivalent to about 31 pounds, this policies has brought adverse effects on domestic prices of the most of goods, since the Sudanese economy depend mainly on imported goods.

8- Notwithstanding ,to cover budget deficit and to purchase the Gold the government embarked on printing large amount of money, which resulted in pushing up the general price level and put high pressure on exchange rate market. 


\section{RECOMMENDATIONS:}

Referring to the above discussions and concluding points the study summarizes the following main recommendations:

1- These finding reinforce the need for comprehensive packages of fiscal and monetary policies by strengthen its framework and improve effectiveness.

2- Unification of multi-exchange rate should be given priority.

3- The need to rationalize administrative fees and taxes leaved on Gold production activities as the most promising targets for revenues and to compact smuggle.

4- The need to increase exports by revitalizing agricultural sector, expanding mining sector, encourage inflows of remittances of Sudanese working abroad and attracting of foreign direct investments.

5- Review recent custom duties on imports and other fees and taxes on exports sector to be more competitive in international markets.

\section{Limitations Of The Study:}

There are some conceptual and methodological obstacles prevent coherent empirical analysis, because of data limitations and its inconsistency related to the length and quality of time series data; market imperfections; multiple exchange rate practices and unstable fiscal policies in addition to other variables complicated the output of this study. Also the existence of sever foreign exchange rate restrictions prevent meaning full estimation of real policy shocks on official and parallel exchange rate volatility in Sudan.

\section{References}

Ahmed Badawi,(2002)"Private Capital Formation and Macroeconomic Policies in Sudan: Application of Simple Co-integration Vector Autoregressive Model " University of Khartoum Press,p.o.Box11115.

Antonio.A\&Ricardo M(2009)"The Macroeconomic Effects of Fiscal Policy" European Central Bank, working paper No.991.

Aron, J. and Elbadawi, I. (1992) "Parallel Markets, the Foreign Exchange Auction, and Exchange Rate Unification in Zambia”, Policy Research Working Papers, No.909, World Bank, Washington, D.C. USA.

Benjamin,Falka\&Muller(2012)," Exchange Rate and Fiscal Multipliers" CEPR and info.institute,F41,E62.

David P\&Shang-Jin(2014) "Fiscal Policy and Real Exchange Rate " financial markets research centre at Vanderbilt university, jel f32

Ebaidalla.Ebaidalla(2017)"Parallel Exchange Market for foreign Exchange in Sudan :Determinants and Impact on Macroeconomic Performance,ERF23rd, Amman, Jordon.

Ebaidalla.M Ebaidalla.(2013)"Impact of Exchange Rate Volatility on Macroeconomic Performance in Sudan"

Elbadawi, I. (1992), "Macroeconomic Management and the Black Market for Foreign Exchange in Sudan”, Policy Research Working Paper, No. 859. World Bank, Washington, D.C. USA.

Faik K\&W.Doglas(2006) "Fiscal Shocks, the Trade Balance, and the Exchange Rate" Mcmillin,eokora@ Isu.edu

Gilbert.D \&Daniel C (2017) " Exchange Rate Fluctuation, Stock Market Performance and Economic Growth in Nigeria Under Democratic Dispersion" International Journal of Innovation Research and Advanced Studies(IJRAS),vol.4,issue.1

Hassan Darabi(2014) " Economic Fluctuation and its Effects on Tourism in Kish Island, Iran" journal of tourism,ISSN,vol.2.

https://www.researchgate./publication

IMF, Group Report(2013)" Monetary Transition Mechanism in Sudan" IMF, Washington DC.

Jeffery S\&Charles w(1984) "Real Exchange Rate Effect of Fiscal Policy" National Bureau of Economic Research,Cambridge,MA02138

Kalid H.Siddig(2011) " The Controversy of Exchange Rate Devaluation in Sudan: An Economy-Wide General Equilibrium Assessment " Agricultural economics, Working paper series, Khartoum University,No2.

Kiguel. A. and O'Connel, S. (1994), "Parallel Exchange Rates in Developing Countries: Lessons From Eight Case Studies", Policy Research Working Papers, No. 1265. World Bank, Washington, D.C. USA.

Koti Reddy\&Agraharic(2012), "Impact of Fiscal Stimulus on Stock Market and Economy " Economic and Business Journal,vol.4,No.1

Maddala,G.S.(1992).Introduction to Econometrics .Macmillan Publishing Company, New York, 2nd Ed. 
Mahran\&Gangi(1996),"Causes of Inflation in the Sudan(1970-1991)" Eastern Africa Social Science Research Review(EASSRR)Vol.xii,no.2

Manyok A John(2016) "Effect of Exchange Rate Fluctuation On Financial Performance of Commercial banks in South Sudan " unpublished research project, university of Nairobi

Mohammed,L\&Sulaiman.D(2010),"The Sources of Real Exchange Rate in Pakistan " European Journal of Social Science.vol.14

Nowak, M. (1984), "Quantitative Controls and Unofficial Market in Foreign Exchange, A Theoretical Framework”, IMF Staff Papers, Vol. 31, No. 2, pp. 404-431.

Richard C\&Joe P(1999)"Fiscal Policy and Real Exchange :some empirical estimates " National Bureau of Economic Research,Cambridge,MA02138

Suliman,Z.Abdalla(2016)"Modeling the Sources and Impact of Macroeconomic Fluctuation in Sudan" Institute of Development Economic, Japan

Taghi N.\&Zomini(2015) " The Impact of Monetary and Fiscal Policies on Iran,n Stock Market" An SVAR Approach,Journal of Applied Environmental and Biological Sciences, www.textroad.com

Trust.R(2016) "The Determinants of Exchange Rate Volatility in South Africa" Eras' Economic Research, South Africa, working paper.604

\section{Appendix (1)}

Table(5-4) lag selection criteria

VAR Lag Order Selection Criteria

Endogenous variables: D(LOEXRT) D(LGT) D(LGDPT)

Exogenous variables: $\mathrm{C}$

Date: $12 / 11 / 17 \quad$ Time: $10: 37$

Sample: 19972017

Included observations: 16

\begin{tabular}{|c|c|c|c|c|c|c|}
\hline Lag & $\log L$ & LR & FPE & AIC & $\mathrm{SC}$ & HQ \\
\hline 0 & 37.84684 & NA & $2.58 \mathrm{e}-06$ & -4.355855 & -4.210995 & -4.348437 \\
\hline 1 & 42.58891 & 7.113111 & $4.53 \mathrm{e}-06$ & -3.823614 & -3.244173 & -3.793942 \\
\hline 2 & 47.36636 & 5.374623 & $8.99 \mathrm{e}-06$ & $-3.295795^{*}$ & -2.281772 & -3.243868 \\
\hline 3 & 69.96676 & $16.95031 *$ & $2.60 \mathrm{e}-06$ & -4.995846 & -3.547242 & -4.921665 \\
\hline 4 & 102.9095 & 12.35352 & $4.70 \mathrm{e}-07 *$ & -7.988684 & $-6.105499 *$ & $-7.892250 *$ \\
\hline
\end{tabular}

* indicates lag order selected by the criterion

LR: sequential modified LR test statistic (each test at $5 \%$ level)

FPE: Final prediction error

AIC: Akaike information criterion

SC: Schwarz information criterion

HQ: Hannan-Quinn information criterion

\section{Appendix (2)}

figure(5-1)

IRFs, fiscal policies shocks on oexrt, , US economic sanction

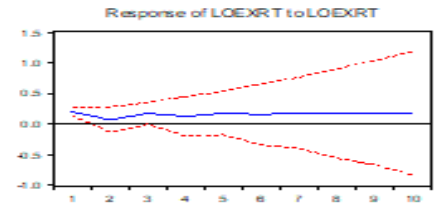

Peesponse of LGT bo LOSXET

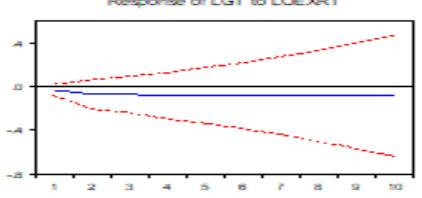

Resporse of DUMYYG to LOEDRT

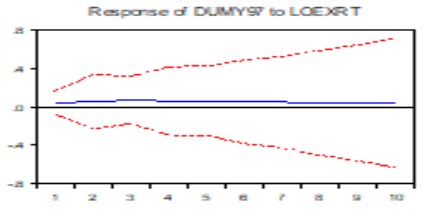

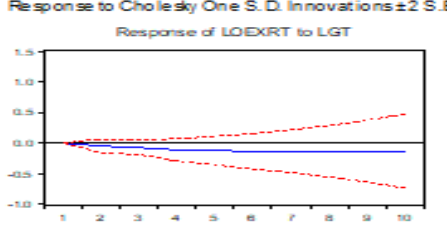

Repprse of LGT toLGT

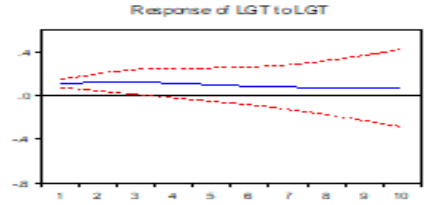

Paspromes of DUM

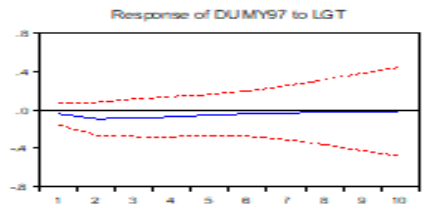

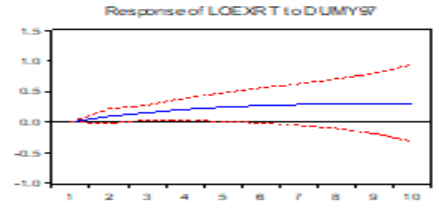

Pesporse of LGT to DUMM?

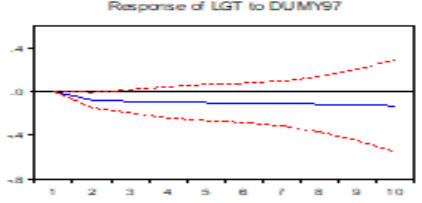

Pesponse of DuMre7 to Duurre

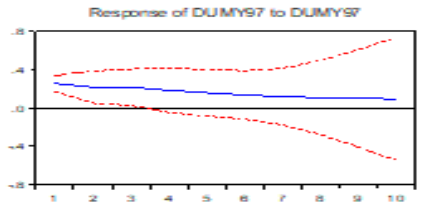




\section{Appendix (3)}

figure (5-2)

IRFs, fiscal policies shocks on oexrt, South Sudan referendum Response to Choleshyone S.D. Innovations \pm 2 S.E.
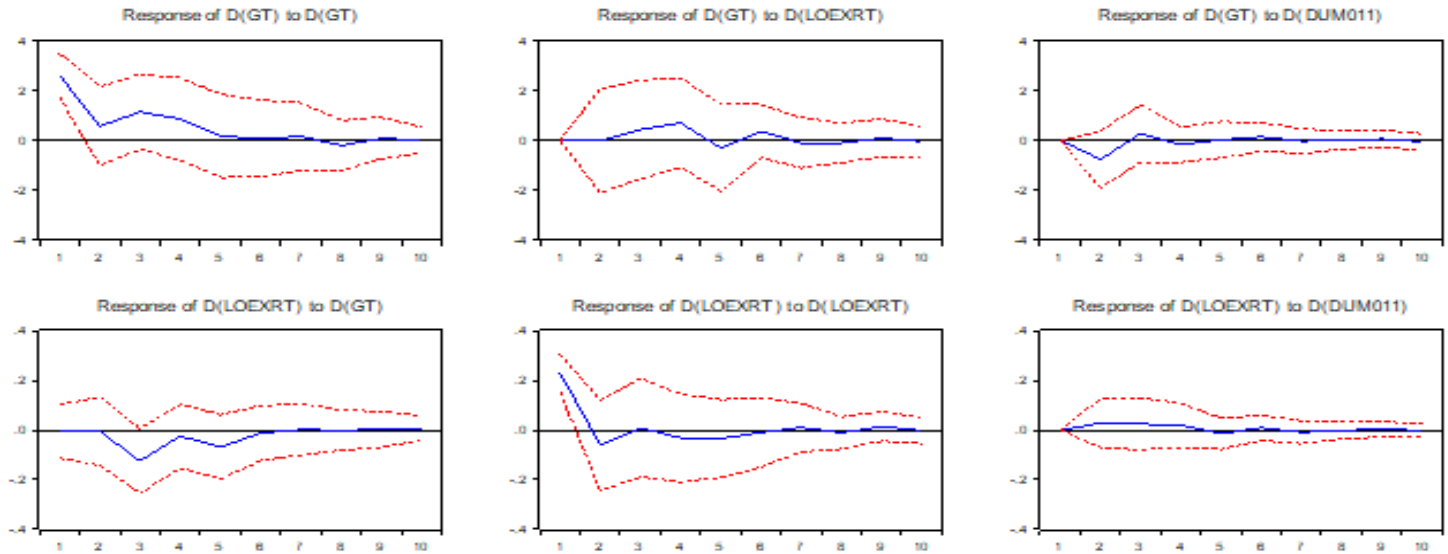

Resparse of D(LOEXRT) to D(DUM011)
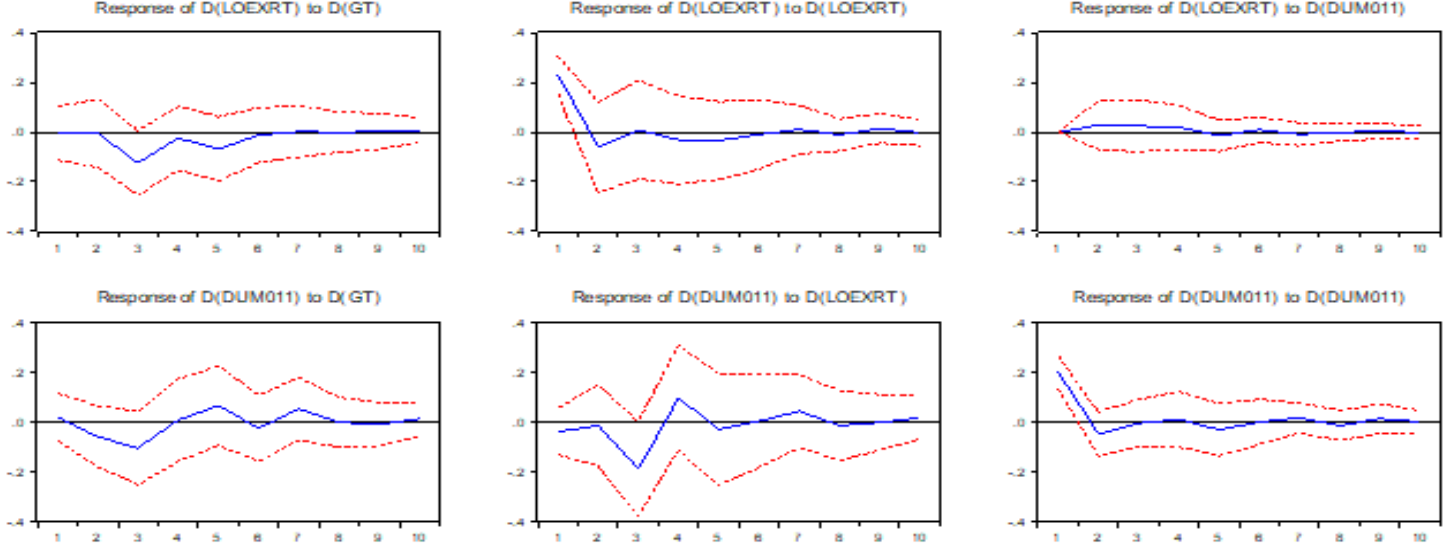

\section{Appendix (4)}

figure(5-3)

IRFs, fiscal policies shocks on pexrt, US economic sanction

Response to CholeshyOneS.D. Innovationst2 S.E.

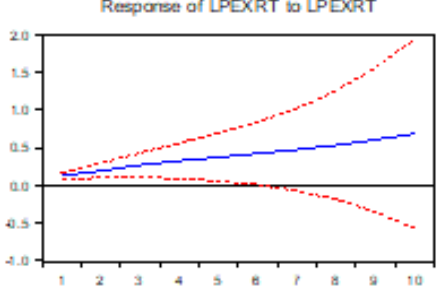

Response of LPEXRT to LGT

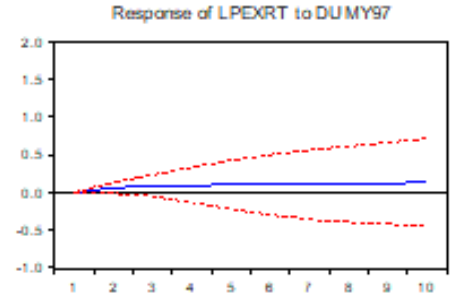

Respornse of LGT to LPEXRT

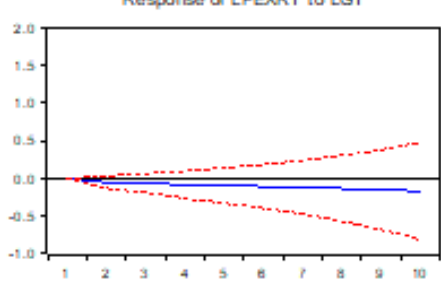

Response of LGT to DUMY97

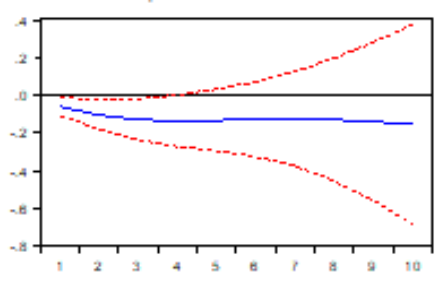

Response of LGT to LGT
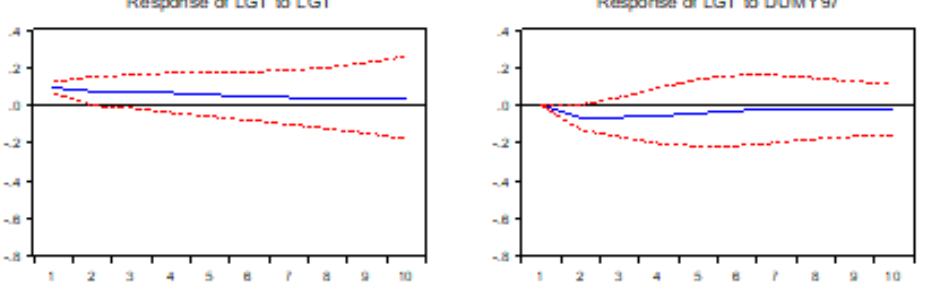

Resporise of DUMY97 to LPEXRT
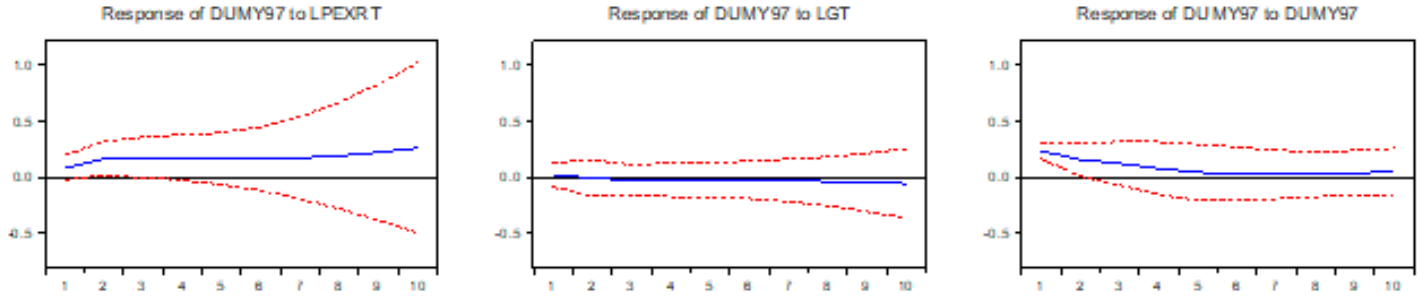
figure(5-4)

IRFs, fiscal policies shocks on pexrt, South Sudan referendum

Response to CholeshyOne S.D. Innovationst2 S.E.

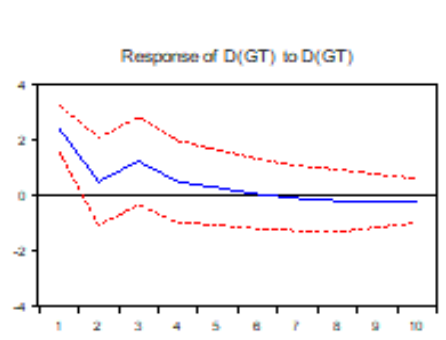

Response of D(GT) to D(LPEXRT)
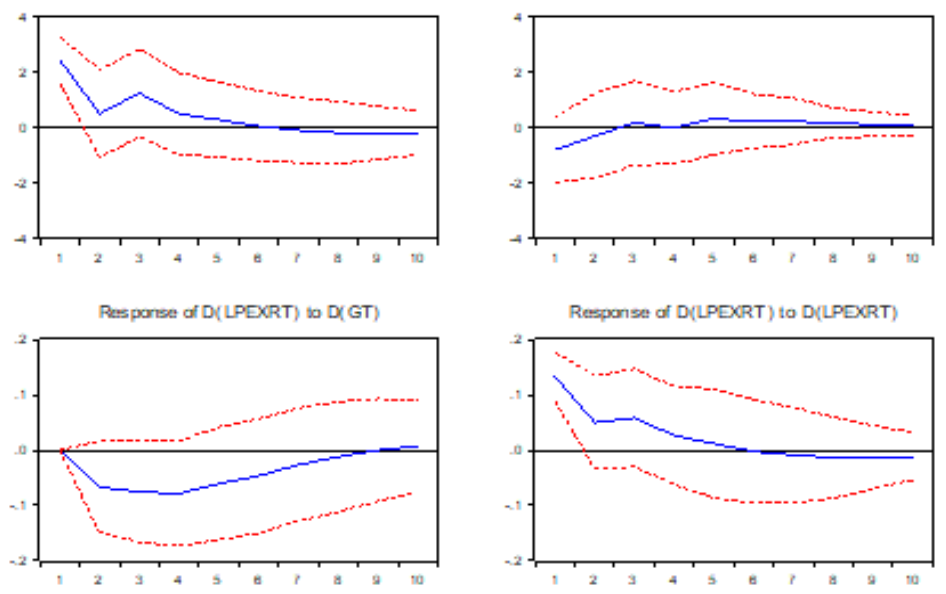

Resporsee of D(DUM011) to D(GT)

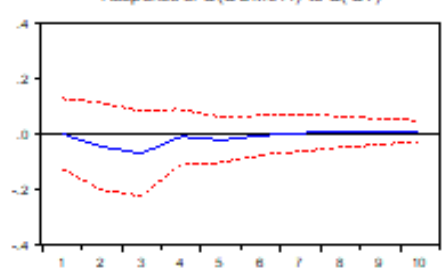

Respanse of D(LPEXRT) to D(LPEXRT)

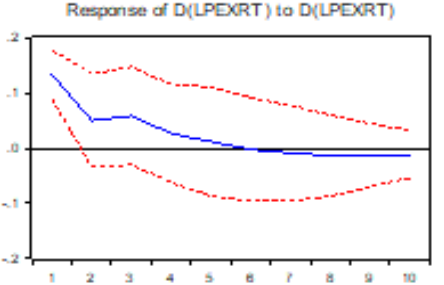

Resporse of D(DUM01 1) to D(LPDCRT)

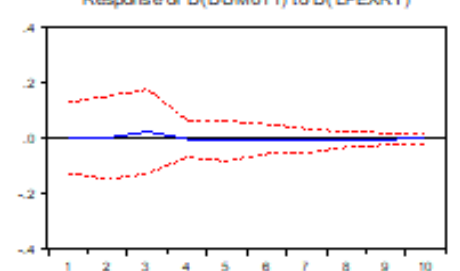

Resporse of D(GT) to D(DUMo11)

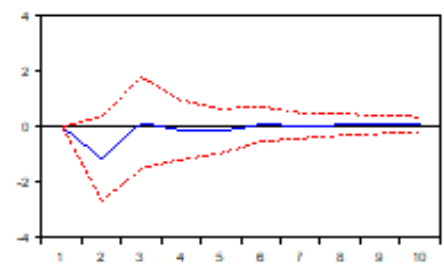

Response of D(LPEXRT) to D(DUM011)

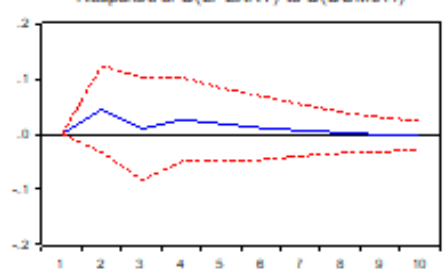

Resparse of D(DUM011) to D(DUM011)

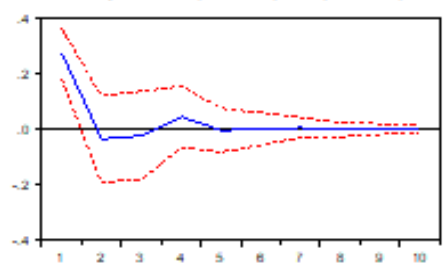

